\title{
Reassurance Policing and Signal Crimes
}

Andrew Millie

\section{PRE-PUBLICATION VERSION}

Published as:

Millie, A. (2014) 'Reassurance Policing and Signal Crimes', in G. Bruinsma and D.

Weisburd (eds.) Encyclopedia of Criminology and Criminal Justice, New York: Springer, pp.4327-4335.

\section{Synonyms}

Neighborhood policing (UK); Signal crimes perspective

\section{Overview}

A reassurance function for policing was first considered by American psychologist Charles Bahn (1974: 338) as "feelings of safety that a citizen experiences when he knows that a police officer or patrol car is nearby." This idea was taken forward in Britain by Martin Innes and colleagues in the early 2000s through the development of a signal crimes perspective. At this time, British policing implemented a National Reassurance Policing Programme (NRPP) where local policing priorities were decided through consultation with local communities. The impact of reassurance policing has since spread and the approach has also been considered in Australia, Belgium, the Netherlands, and Sweden.

In this entry, the background to reassurance policing is considered with particular reference to the work of Charles Bahn and Martin Innes and colleagues. The development of a policy of reassurance policing in Britain is also examined. The successes and limitations of the approach are considered and three main issues identified: that reassurance needs to be a consideration for all policing; that increases in visible patrol need to be questioned (especially at a time of budget restraint); and that reassurance policing has the potential to be a model of democratic policing, but only if consultation is truly inclusive, for instance, including those that have been victimized and groups that have been targets of police activity such as young people, the homeless, and other minority and marginalized groups. 


\section{Fundamentals}

"Reassurance policing" is an approach to policing that emphasizes the importance of the police communicating a positive image to the public, that the public is reassured that the police are doing a good job. It is closely allied to "community policing," "community-oriented policing services" (COPS), and "neighborhood policing." The first to write about the reassurance function of policing was American psychologist Charles Bahn (1974). The context was the publication of the Kansas City Preventative Patrol Experiment (Kelling et al. 1974). According to the then Kansas City Chief of Police, Joseph D. McNamara (Kelling et al. 1974: vii), the experiment showed that "routine preventive patrol in marked police cars has little value in preventing crime or making citizens feel safe." However, Bahn suggested police patrol still had an important function by increasing public awareness of police work and thereby providing visible reassurance (and hopefully making the public feel safer). He defined the reassurance function in the following terms:

In addition to its more obvious functions, police patrol also has the function of citizen reassurance - providing feelings of safety that a citizen experiences when he knows that a police officer or patrol car is nearby. (Bahn 1974: 338)

Bahn's definition emphasized subjective feelings of safety rather than any objective measure, and the best way to provide reassurance, to make the public feel safer, was through visible and accessible police patrol:

... when the man in the street asks for more police, he is really asking for the police to be on hand more frequently and more conspicuously when he is going about his daily business. (Bahn 1974: 340-341)

After Bahn, there followed a long period during which time the reassurance function was not a major focus for policing. Crime continued to rise and so controlling the level of crime was the clear priority. Rather than focus on patrol, emphases were increasingly on professionalism and crime management, a decision that appeared to be backed by the research. Not only did the Kansas City Experiment question the value of patrol work (Kelling et al. 1974), but also the Newark Foot Patrol Experiment (Kelling et al. 1981). In this study, George Kelling's team found that foot patrol did not reduce crime. However, more positively - and in support of Bahn's position - they also found that foot patrol did have an impact on fear of crime and police satisfaction (see also Clarke and Hough 1984).

Yet, a performance culture evolved in North America, Britain, and many other western nations more focused on crime control and prevention - for example, through forms of zero-tolerance or intelligence-led policing (Innes 2004). In Britain, in the late 1990s and early 2000s, the focus had become volume crime while neglecting more minor disorders and antisocial behaviors (Millie and Herrington 2005). According to FitzGerald et al. (2002: 118), "quantitative performance management was narrowing the focus of police activity in ways that might put long-term investment in police-community relations at risk." 
At a time of rising crime, there were also high levels of fear of crime. However, from the mid1990s onward, recorded crime rates fell in most western nations. This fall in crime was not thought to be matched by falls in fear of crime (Innes 2004). The meaning and measurement of fear of crime are contested and the problem could be exaggerated (Farrall and Gadd 2004). There is not a straightforward relationship between crime rates, police activity, and fear of crime; in fact, in some jurisdictions, an aggressive approach to crime by the police may have resulted in greater fear of crime among marginalized populations (Innes 2004). Also, according to Innes, an emphasis on crime management meant that much police work became behind-thescenes analysis that was not visible to the public. An unintended consequence was an increased "social distance between police and policed" (Innes 2004: 156).

However, despite claims that the level of fear of crime was a problem, British Crime Survey measures of "worry about crime" did fall from the mid-1990s (Millie and Herrington 2004, 2005). Of greater importance than fear of crime - for a policy of reassurance policing - is public confidence in the police. In Britain, public confidence declined at the same time that recorded crime rates fell (Hough 2003). Furthermore, members of the pubic were unaware that crime rates had been falling; for instance, according to the Audit Commission (1999: 2): "Recorded crime fell by 14 per cent from 1995 and 1997, but fewer than one person in ten was aware that crime had decreased over this period." The disjuncture between falling crime, the public's ignorance of this fall (with many thinking it was rising), and falling confidence in the police became known as the "reassurance gap." Feeding into this were concerns about fear of crime. British police introduced a policy of "reassurance policing" at the start of the new millennium as a response to concern over the "reassurance gap." The answer to falling public confidence in policing was not it seemed greater managerial focus on performance, but a shift in focus to people's perceptions:

The current over-focus on crime figures as a substitute measure for police performance will not lead to greater public confidence. The public is convinced that the UK is a highcrime society. A reassurance strategy will provide an opportunity to shift people's perception and begin to change the embedded culture of fear of crime. (ACPO 2001: para.5.3)

A focus on perceptions and feelings has been criticized. For some, the approach acquired the nicknames of "there, there policing" or "big hug policing" (Millie and Herrington 2004: 4). For others, it was little more than a public relations exercise and a re-branding of earlier attempts at community policing. According to FitzGerald et al. (2002), giving the impression that the public are safer without also tackling crime rates is hard to justify:

If reassurance policing yields reductions in crime and disorder as well as reassurance, it is hard to see how it differs from effective policing. If it doesn't yield these reductions, the case for it needs scrutiny. It is difficult to justify devoting limited police resources to policing activity that serves only to give people the impression they are safer from crime (FitzGerald et al. 2002: 132, emphasis in original). 
The UK Home Office embraced the idea of reassurance policing and commissioned a study, "to identify ways to free-up officers' time" in order to perform reassurance policing (PA Consulting 2001: v). According to the PA Consulting report, reassurance policing was defined as:

... any sectoral policing activity that is visible within the community. It is the visibility of the policing effort that provides the reassurance. Hence, reassurance policing includes patrols - either directed or uncommitted, mobile or on foot - as well as visible policing of incidents. Reassurance policing is designed to address not only crime, but the fear of crime (PA Consulting 2001: 1).

PA Consulting extended the definition from Bahn's visible patrols to any form of policing that is visible to the public. The emphasis was on visibility as a means to address fear of crime. At the same time, a report by Her Majesty's Inspectorate of Constabulary (HMIC) investigated "the role of police visibility and accessibility in public reassurance" (Povey 2001). For the HMIC report (Povey 2001: 20) reassurance was defined as "the extent to which individuals perceive that order and security exist within their local environment." While PA Consulting focused on visibility, the HMIC report broadened this to "visibility, accessibility, and familiarity" (Povey 2001):

- "Visibility: the level, profile and impact of police resources deployed within local communities.

- Accessibility: the ease with which the public can obtain appropriate police information, access services or make contact with staff.

- Familiarity: the extent to which police personnel know, and are known by, local communities." (Povey 2001: 23-24).

Taking the different definitions together reassurance is a subjective state influenced by perceptions/sense of order and security, and by fear of crime. The job of reassurance policing is to address these subjective feelings through increased police visibility, accessibility, and familiarity. Put simply, according to Innes (2007: 135), the police are assumed to have "an important role to play not just in making people safe but in making them feel safer also."

Key to this is the semiotic quality of police public encounters, whether this is while on patrol, when an incident is reported, through calls for service or any other mediated communication. Semiotics is an approach that attempts to understand the communicative quality or sign-value of things. Policing communicates different messages to different publics and this may be intimidation and suppression, or more positively, efficiency and reassurance. What the police communicate will be influenced by reputation, levels of trust and respect, experience of policepublic encounters, and visual cues such as the uniform, police car, or even station architecture and design (Millie 2010, 2012). Also of relevance here is symbolic interaction. For instance, drawing on Goffman (1959/1990) Innes posits that, "the reassurance function of policing recognises and seeks to harness the dramaturgical power of formal social control" (Innes 2007: 133). In effect, the police officer's role is a performance of control and reassurance. 


\section{The Signal Crimes Perspective}

In Britain, the communicative qualities of policing were the focus of the "signal crimes" perspective developed by a team from Surrey University, led by Martin Innes and Nigel Fielding (e.g., Innes and Fielding 2002). Alongside the influence of Bahn's work on police reassurance, the signal crimes perspective was informed by psychological research into risk perception, especially that of Paul Slovic (1992). According to Slovic, risk can be amplified by a combination of "psychological, social, cultural, and political factors" (1992: 124). Slovic contended that each risk-related event holds a "signal value," reflecting "the perception that the event provides new information about the likelihood of similar or more destructive future mishaps" (1992: 124). For the signal crimes perspective, this idea was transferred to criminogenic risks. According to Innes and Fielding (2002: 3.6):

... public understanding of the seriousness of a risk is not defined solely by the characteristics of the event itself. Rather, it is the nature of the risk, it's semiotic properties, together with the context in which it occurs, that shapes how it is interpreted and understood.

From this perspective, it is not the seriousness of an event (however that is measured), but the signal value of an event that has the biggest effect. This will be influenced by a range of factors including, for example, perception of seriousness and impact on individual or neighborhood, frequency, time and location of event, behavioral expectations, and media coverage. Innes and Fielding went on to state that "the most important incidents in shaping popular fear and anxiety may not necessarily be only those that are traditionally defined by juridical discourses as serious crimes" (2002: 3.6). In fact, they concluded, it could be "relatively trivial" disorders, incivilities, or antisocial behaviors in one situation, but serious crimes in another that have the greatest signal value. According to Innes and Fielding (2002: 5.2):

A signal crime/event can be defined as an incident that is disproportionately influential in terms of causing a person or persons to perceive themselves to be at risk in some sense.

The signal crime has disproportionate effect on perceptions of security, it is a warning that something is perceived to be wrong with a neighborhood or with society in general. By focusing police attention on whatever is identified as the signal crime(s) for a particular neighborhood, the hope is that there will be bigger gains in improving feelings of security and reassurance. For the police to adopt a signal crimes approach, they need to consult various publics and identify which crimes or disorders act as "signals" in particular neighborhoods. There can be strong and weak signals and not everyone will interpret the signals the same way, or the same in different spatial-temporal contexts; for instance:

What for young people is merely part of their normal routine and lifestyle (i.e. hanging around on street corners during the evening), may be construed by older residents as signals that they should not go out at night, in order to avoid threats to their safety. (Innes and Fielding 2002: 5.10). 
There is a risk that certain "usual suspects" may be unjustly perceived as signals of disorder, for instance, including young people who congregate, the street homeless, or other minority and marginalized populations. If police enforcement policy is informed by a signal crimes perspective, then the disproportionate targeting or "zero tolerance" of those labeled as signals would need to be avoided. A similar criticism has been levelled at the "broken windows" perspective of Wilson and Kelling (1982); in fact, "broken windows" and "signal crimes" have a lot in common. For the broken windows perspective, disorder is "read" as an indicator of decline, causing people to withdraw from disorderly areas leading to a decline in informal social control, thus making crime more likely. In effect, disorder is thought to cause crime to occur. However - drawing on Sampson and Raudenbush (1999) - Innes and Fielding contend that disorder does not lead to crime, but that crime and disorder are functionally equivalent: "Thus disorder is part and parcel of crime itself. Graffiti does not cause robbery, but a lack of informal social control is a cause of both" (Innes and Fielding 2002: 4.3). Alongside certain crimes, disorders, or people having a "signal value," Innes and colleagues posited that the police can act as "control signals," especially through visible patrol. This is supported by the informal social control enacted by active communities.

According to Innes (2004), "reassurance" is a style of policing that can deliver enhanced security and is not in itself an outcome. For Innes (2004), reassurance policing consists of these three parts:

- "high visibility patrols performed by officers who are known to the local public;

- the targeting of 'signal crimes' and 'signal disorders'; and

- informal social control performed by communities" (Innes 2004: 151).

\section{The British National Reassurance Policing Project (NRPP)}

From 2002 to 2003, a strategy trial of reassurance policing was run by Surrey Police and the Metropolitan Police in association with the Association of Chief Police Officers (ACPO) and the Home Office. The business case for the strategy trial had five elements:

- Public confidence in police choices and solutions through identifying "signal" concerns through public consultation

- Visible control - public reassurance by seeing visible proof that their problems are important to the police and are being controlled

- A targeted, intelligence-led approach focusing resources on community signals through problem solving

- Joint action from the police and other partner agencies

- Dedicated resources as much as is practicable (Millie and Herrington 2005) 
A range of methods were utilized in order to identify which crimes and disorders acted as "signals" (Innes et al. 2009). In the first instance, drawing on the work of Sampson and Raudenbush (1999) and others, a visual/environmental audit was conducted of a neighborhood to identify potential "signal crimes" and "control signals." Secondly, drawing in particular on the Chicago Alternative Policing Strategy (Skogan and Hartnett 1997), local people were consulted on what were perceived to be signals. This was through the use of public perception surveys and community consultation groups. The Surrey University team also interviewed individual residents using maps to guide responses (Innes et al. 2009).

The full National Reassurance Policing Project (NRPP) was launched in 2003 and operated until 2005 in 16 sites located across eight force areas. The eight forces were Greater Manchester Police, Lancashire Police, Leicestershire Police, Metropolitan Police, Merseyside Police, Surrey Police, Thames Valley Police, and West Midlands Police. The program was evaluated by the Home Office (Tuffin et al. 2006). According to the Home Office evaluation, the NRPP aimed to achieve:

- "Reduced anti-social behaviour and improved quality of life;

- Reduced fear of crime and improved sense of safety;

- Increased public satisfaction with, and confidence in, the police; and,

- Improved social capacity" (Tuffin et al. 2006: xi).

This was an ambitious list. In fact, on the ground, reassurance policing was interpreted as having other additional objectives (Millie and Herrington 2005). For instance, the approach was regarded as a means of gathering community intelligence. Furthermore, it was thought to provide much needed structure to community policing, to lead to improvements in the local environment, and to reduce overall crime. According to Millie and Herrington (2005: 53), the central focus of reassurance policing needed to be to improve confidence in the police and to provide legitimacy for policing decisions. According to the Home Office evaluation, the aims of the NRPP were to be achieved through:

- "Targeted policing activity and problem solving to tackle crimes and disorder which matter in neighbourhoods;

- Community involvement in the process of identifying priorities and taking action to tackle them; and

- The presence of visible, accessible and locally known authority figures in neighbourhoods, in particular police officers and police community support officers" (Tuffin et al. 2006: xii).

The involvement of communities in identifying policing priorities can be regarded as part of broader "localism" agendas. According to the Home Office evaluation, after program implementation, more people thought crime had decreased, there were positive effects on public satisfaction with the police, and positive effects on perceptions of antisocial behavior 
and of feelings of safety (but not on fear of crime). Furthermore, there were improvements in levels of police visibility and familiarity and in public engagement. That said, public attendance at meetings was no greater in trail sites than it was in control sites (Tuffin et al. 2006). It was suggested that public consultation should extend beyond standard public meetings to include "street briefings, door knocking and 'have a say days"" (Tuffin et al. 2006: xvi), and when extra effort was put into public engagement, this was noticed by the public. The conclusion of the evaluation was as follows:

The research did not provide a test of the 'signal crimes' perspective, developed by Martin Innes, but does suggest that a policing approach which targets public priorities can have a positive impact both on crime and on public perceptions. . . The limited improvements in worry and social capacity indicators suggest the need for further survey work to examine future change in the sites. (Tuffin et al. 2006: 95).

By 2004, policing policy was already moving forward with, in the Metropolitan Police, the emergence of a Safer Neighbourhoods Programme (Herrington and Millie 2006). This evolved into a national Neighbourhood Policing Programme (Innes 2005) and by 2008, Neighbourhood Policing Teams were allocated across all of England and Wales (Millie 2010). Key elements of reassurance policing survived in this new format.

In Britain, policing policy is very much tied in with national politics and in 2010, a new Conservative-led coalition government came into power. The financial crisis led to a decision to cut public sector finance - including a $20 \%$ cut in central government funding of policing (Millie and Bullock 2012). It was not certain how reassurance/neighborhood policing would survive and in what form. That said, the coalition emphasized localism with the first democratically elected Police and Crime Commissioners in Britain introduced in November 2012. Reassurance policing's emphasis on community involvement could be attractive to the newly elected Commissioners.

\section{Issues and Controversies}

The Home Office evaluation of Reassurance Policing was broadly positive regarding the approach's effectiveness. The approach may not have had much of an impact on fear of crime or on social capacity, yet the improvements in perceptions of crime and antisocial behavior and public attitudes toward the police were not insignificant. Yet there are potential issues and controversies with the approach, which are outlined here.

\section{Just Another Form of Community Policing}

Firstly, there was always a risk that reassurance policing would be viewed as "just another project" or the same as community policing but under a different banner (Herrington and Millie 2006). While some of those involved in theNRPP thought it was the same as before, others saw it as something much more. For one officer involved in the strategy trial, the approach needed to be a "golden thread" running through all policing (Millie and Herrington 2005: 54) and not just a consideration for those involved directly in the project. There is a danger that if 
reassurance is restricted to a particular project, then those not involved could ruin any advances made by "loose talk" or "loose action." For instance, this could be by disproportionate targeting of "usual suspect" minority populations; or it could be the removal of police identification numbers during public protest, as has occurred in Britain (Millie 2010). If reassurance is a "golden thread" through all policing, then such activities would be questioned.

\section{Reassurance and Visibility}

A further focus for reassurance policing is improved police visibility. An original intention for reassurance policing, as outlined by Bahn (1974), was for officers to be a fixed point of reference on the street. This part of Bahn's approach was not incorporated into the NRPP; however, there is scope for improved visible (and fixed point) reassurance through the effective use of police stations and neighborhood bases in a similar fashion to the Japanese system of koban (Millie 2010).

Popular politics frequently call for more police officers on the beat, irrespective of their seemingly low effectiveness in reducing crime, as famously demonstrated by the Kansas City experiment. Instead, the police are there to be seen so as to improve people's feelings of security. According to Loader (2006: 207), there is a "self-propelling circle whereby popular demands, and the numbers of police supplied in a bid to meet them, are both endlessly ratcheted up." There are clear resource implications of highly visible policing. At a time of fiscal restraint, the deployment of large numbers of locally based officers, with a remit to be highly visible, becomes less of an option.

\section{Reassurance Policing as Democratic Policing}

A central focus for reassurance policing is that neighborhood priorities are identified by the community. There is a risk that such locally identified priorities will be in conflict with force or national policing objectives. Furthermore, there is an assumption that all neighborhoods want police intervention (some may prefer the police to go away).

Yet, on the surface, the approach is a commendable example of democratic policing. Legitimacy in policing decisions is maximized as decisions are made by "the community" rather than being dictated by police or government hierarchy. However, there is a potential problem that those consulted may not represent all the multiple communities that live in a neighborhood. Furthermore, they may constitute the "worried well," rather than a group with experience of victimization (Millie 2010). In such cases, the "signal crimes" identified will be based on perception more than actual crime and antisocial behavior (Crawford 2007). The involvement of "hard to reach" or less visible or vocal groups is notoriously difficult (e.g., Skogan and Hartnett 1997). And, as already noted, there is a danger that "usual suspects" such as young people, street homeless, or other minority and marginalized populations - will become labeled as "signals" and disproportionately policed. According to Loader (2006), if those consulted have expectations for "total security" that cannot be met, then even they may not be reassured. Furthermore, there is a danger that those consulted may suffer consultation fatigue and the police will just assume they know what is required, as Herrington and Millie (2006: 159) have observed: 
... we were frequently told that the police knew what the concerns were, the public were tired of being consulted and just wanted something done. This may turn out to be the case, but effective and inclusive consultation is essential if policing is to avoid a "ready, fire, then aim" criticism that is often levelled at them when adopting new initiatives.

\section{Conclusions}

The idea of "reassurance policing" was first considered in the USA through the work of psychologist Charles Bahn (1974). However, it was not until the early 2000s in Britain that it was taken forward by Martin Innes and colleagues with the development of the signal crime perspective. A theoretically informed method was developed for delivering a reassurance approach to policing and reassurance policing became a major strand of British policing policy. The approach has also had wider international impact. For instance, reassurance policing has also been considered for policing in Australia, Belgium, the Netherlands, and Sweden.

The evaluation of the NRPP in Britain was largely positive, that reassurance policing has the potential to provide an approach that can improve confidence in the police and improve perceptions of crime and antisocial behavior. There are however obstacles that would need to be negotiated in order to maximize effectiveness:

- Firstly, reassurance would need to be integral to all policing activity, from call handling through to public order policing. Reassurance would be most effective as a consideration for all officers, rather than as a bolt-on extra and only a concern for a smaller number of "community" or "reassurance" officers.

- Secondly, the assumption that more and more visible officers are always better would need to be questioned, especially at a time of fiscal restraint. Other forms of improved visibility could be investigated, such as improved use of police stations and neighborhood bases/shop front offices.

- Thirdly the democratic potential of reassurance Policing would need to be taken seriously that consultation does not focus on the "worried well," but instead the views and experiences of those who have been victimized or have been the targets of police action are actively sought. To be truly inclusive and reassuring to all community members, consultation would need to include young people, the homeless, and other minority and marginalized groups. 


\section{Related Entries}

-British Police

-Democratic Policing

-Early Modern Police and Policing

Evidence-Based Policing

Law of Community Policing and Public Order Policing

-Measuring Police Performance

-Order Maintenance Policing

-Organizational Change and Police Legitimacy

PPolice Culture

-Police Discretion in Law Enforcement

-Police Discretion in Providing Services and Assistance

Police Integrity

-Police Legitimacy and Police Encounters

-Police Self-Legitimacy

Role and Function of the Police

-Theories on Policing and Communities

\section{Recommended Reading and References}

ACPO (2001) Reassurance - civility first: a proposal for police reform. Association of Chief Police Officers, London

Audit Commission (1999) Safety in numbers: promoting community safety, briefing, February 1999. Audit Commission, London

Bahn C (1974) The reassurance factor in police patrol. Criminology 12(3):338-345

Clarke RV, Hough M (1984) Crime and police effectiveness, Home Office Research Study 79. Home Office, London 
Crawford A (2007) Reassurance policing: feeling is believing. In: Henry A, Smith DJ (eds) Transformations of policing. Ashgate, Aldershot

Farrall S, Gadd D (2004) Research note: the frequency of the fear of crime. Br J Criminol 44(1):127-132

FitzGerald M, Hough M, Joseph I, Qureshi T (2002) Policing for London. Willan, Cullompton Goffman E (1959/1990) The presentation of self in everyday life. Penguin, London

Herrington V, Millie A (2006) Applying reassurance policing: is it 'business as usual'? Polic Soc 16(2):146-163

Hough M (2003) Modernisation and public opinion: some criminal justice paradoxes. Contemp Pol 9(2):143-55

Innes M (2004) Reinventing tradition? Reassurance, neighbourhood security and policing. Crim Just 4(2):151-171

Innes M (2005) Why 'soft' policing is hard: on the curious development of reassurance policing, how it became neighbourhood policing and what this signifies about the politics of police reform. J Community Appl Soc Psychol 15(3):156-169

Innes M (2007) The reassurance function. Policing: J Policy Pract 1(2):132-141

Innes M, Fielding N (2002) From community to communicative policing: signal crimes and the problem of public reassurance. Sociol Res Online 7(2). Available at: www.socresonline.org.uk

Innes M, Abbott L, Lowe T, Roberts C (2009) Seeing like a citizen: field experiments in 'community intelligence-led policing'. Police Pract Res 10(2):99-114

Kelling GL, Pate T, Dieckman D, Brown CE (1974) The Kansas city preventive patrol experiment: a summary report. The Police Foundation, Washington DC

Kelling GL, Pate A, Ferrara A, Utne M, Brown CE (1981) Newark foot patrol experiment. The Police Foundation, Washington, DC

Loader I (2006) Policing, recognition, and belonging. Ann Am Acad Pol Soc Sci 605(1):201221

Millie A (2010) Whatever happened to reassurance policing? Policing: J Policy Pract 4(3):225232

Millie A (2012) Police stations, architecture and public reassurance. Br J Criminol 52(6):10921112

Millie A, Bullock K (2012) Re-imagining policing post austerity. Br Acad Rev 19:16-18 
Millie A, Herrington V (2004) Reassurance policing in practice: views from the shop floor. Papers from the British criminology conference, vol 7. Available at: www.britsoccrim.org

Millie A, Herrington V (2005) Bridging the gap: understanding reassurance policing. Howard J Crim Just 44(1):41-56

PA Consulting (2001) Diary of a police officer, Police Research Series Paper 149. Home Office, London

Povey K (2001) Open all hours: a thematic inspection report on the role of police visibility and accessibility in public reassurance. Her Majesty's Inspectorate of Policing, London

Sampson RJ, Raudenbush SW (1999) Systematic social observation of public spaces: a new look at disorder in urban neighborhoods. Am J Sociol 105(3):603-651

Skogan W, Hartnett S (1997) Community Policing, Chicago Style. Oxford University Press, New York

Slovic P (1992) Perceptions of risk: reflections on the psychometric paradigm. In: Krimsky S, Goulding D (eds) Social theories of risk. Praeger, Westport

Tuffin R, Morris J, Poole A (2006) An evaluation of the impact of the national reassurance policing programme, Home Office Research Study 296. Home Office, London

Wilson J, Kelling G (1982) Broken windows: the police and neighborhood safety. Atlantic Monthly 249:29-38 